\title{
A Functional Optimization based Calculation Scheme for Dynamic Economic Load Dispatch Considering Ramp Rate of Thermal Units Output
}

\author{
Teruhisa Kumano Senior Member (Meiji University)
}

Keywords: thermal power plant, economic load dispatch, output ramp rate, calculus of variations

\section{Introduction}

Economic load dispatch among thermal units has been one of the most important problems in the field of power systems operation. Usually so called equal marginal cost criterion is adopted to this calculation. Recently global trend of utilizing more and more renewable energy makes this problem more important than ever. In case of large penetration of fluctuating power sources such as PV or wind, thermal units are more often required to change their prescheduled operation pattern because the outputs from PV and wind power generators are affected by uncertain change of weather condition. In a sense the large scale utilization of natural energy depends on the flexible and adaptive operation of the thermal units. In such a situation it is easily imagined that thermal units would be required to change their output faster than before sometimes violating the limitation due to the physical constraints of the plant including boilers. We will need a load dispatch calculation method which maximally utilizes their output change capability within the upper and lower limits of the ramp rate.

Dynamic economic load dispatch has been studied for a long time to give appropriate load dispatch among generators considering the above stated constraints. However the existing methods are not enough in case of the scenario of very steep demand change. Some more sophisticated calculation scheme is highly needed today which gives us feasible solution in severer situations.

\section{Proposed Method}

This paper proposes a new calculation scheme (Fig. 1) for the

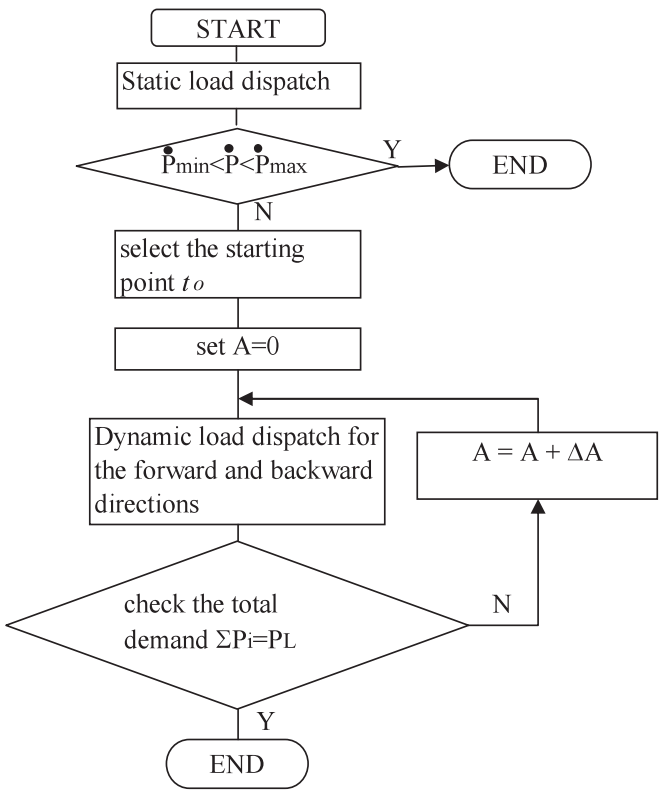

Fig. 1. Proposed method above stated dynamic economic load dispatch problem based on functional optimization which numerically solves Euler's differential equation in the field of calculus of variations. The constraints related to units output and output ramp rate are readily considered by the logarithmic penalty function terms in the objective function together with the equality constraint regarding the total demand balance.

\section{Numerical Example and Discussion}

Numerical examples show that the proposed method can solve the above stated severe situation which has been difficult to treat by the existing methods. By adjusting a parameter A the feasibility of the solution is successfully controlled (Figs. $2 \& 3$ ). The obtained result is slightly less economical than the optimal solution (Table 1) but is feasible.

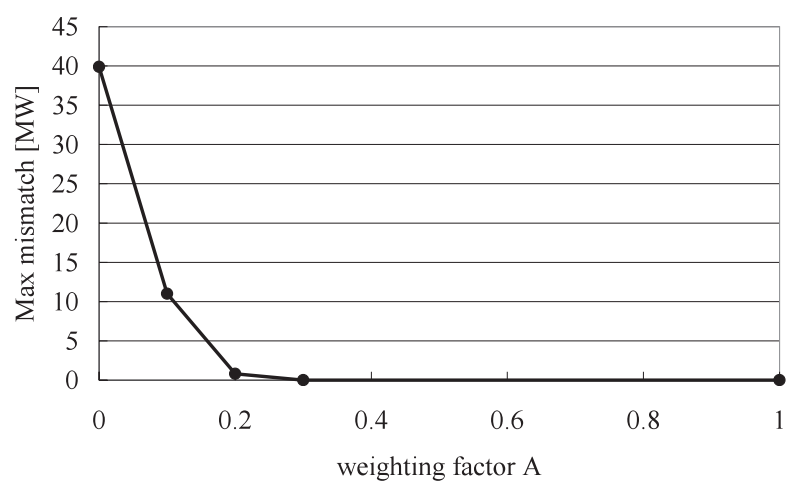

Fig. 2. Elimination of supply/demand mismatch by parameter selection

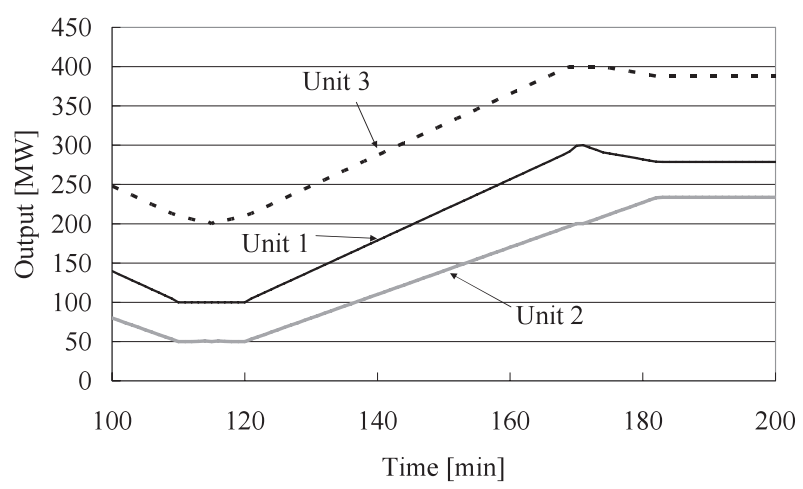

Fig. 3. Obtained feasible solution

Table 1. Total generation cost for various A

\begin{tabular}{c|c|c|c|c}
\hline $\mathrm{A}$ & 0.0 & 0.1 & 0.3 & 1.0 \\
\hline Total cost & 1.000 & 1.018 & 1.034 & 1.038 \\
\hline
\end{tabular}




\title{
火力機出力変化率を考慮した動的経済負荷配分の 関数最適化による計算法
}

\author{
上級会員 熊野 照久*

\begin{abstract}
A Functional Optimization based Calculation Scheme for Dynamic Economic Load Dispatch Considering Ramp Rate of Thermal Units Output
\end{abstract}

Teruhisa Kumano*, Senior Member

\begin{abstract}
Economic load dispatch among thermal units has been one of the most important problems in the field of power systems operation. Usually so called equal marginal cost criterion is adopted to this calculation. Recently global trend of utilizing more and more renewable energy makes this problem more important than ever. In case of large penetration of fluctuating power sources such as PV or wind, thermal units are more often required to change their prescheduled operation pattern because the outputs from PV and wind power generators are affected by uncertain change of weather condition. In a sense the large scale utilization of natural energy depends on the flexible and adaptive operation of the thermal units. In such a situation it is easily imagined that thermal units would be required to change their output faster than before sometimes violating the limitation due to the physical constraints of the plant including boilers. We will need a load dispatch calculation method which maximally utilizes their output change capability within the upper limits of the ramp rate.

Dynamic economic load dispatch has been studied for a long time to give appropriate load dispatch among generators considering the above stated constraints. However the existing methods are not enough in case of the scenario of very steep demand change. Some more sophisticated calculation scheme is highly needed today which gives us feasible solution in severer situations.

This paper proposes a new calculation scheme for the above stated dynamic economic load dispatch problem based on functional optimization which numerically solves Euler's differential equation in the field of calculus of variations. The constraints related to units output and output ramp rate are readily considered by the logarithmic penalty function terms in the objective function together with the equality constraint regarding the total demand balance. Numerical examples show that the proposed method can solve the above stated severe situation which has been difficult to treat by the existing methods. Convergence performance is also discussed.
\end{abstract}

キーワード : 火力発電所, 経済負荷配分, 出力変化率, 変分法

Keywords: thermal power plant, economic load dispatch, output ramp rate, calculus of variations

\section{1. はじめに}

電力系統の需要には日間変動があるため, 安定供給のた めに水力・灭力発電機の出力をこれに合わせて変化させる 必要があるが，その主体は火力発電機である。需要変化を 構成する変動成分のうち十数分程度以上の時定数を持つ比 較的ゆっくりとした成分については経済性を考慮した負荷 配分が給電指令所などで計算され, 火力発電機の出力はこ

\footnotetext{
* 明治大学

干 214-8571 川崎市多摩区東三田 1-1-1

Meiji University

1-1-1, Higashi-mita, Tama-ku, Kawasaki 214-8571
}

れに基づいて設定される ${ }^{(1)}$ 。この際，発電機出力が出力上 下限を逸脱してはならないのはもちろんであるが, 出力変 化率についても上限制約 (変化率制約) がある。しかし, 従 来の経済負荷配分手法により計算された負荷分担では変化 率制約に違反を生じ実現できないことがあり問題とされて きた (2)。この原因は従来の経済負荷配分に使われてきた等 増分燃料費則 (以下, 等 $\lambda$ 法) が個々の時点を静的断面と して扱い, 各発電機の時間方向のトレンドを考慮していな いためである。

この問題は昨今の自然エネルギー発電の大量導入の流れ から再び重要性を増している。すなわち, 太陽光, 風力等 の変動電源の拡大やシステム全体の効率運用および信頼性 
の維持を考慮すると, 火力発電機を含めた制御可能電源の 出力を積極的に増減させることが課題となりうるとの指摘 である ${ }^{(3)}$ 。火力発電機群に変化率制約ぎりぎりの発電出力 変化を従来以上に求める場合，こうした要請に応える上で 有効な問題解決法は意志決定を行う上で重要である。

火力発電機の変化率制約を考慮する経済負荷配分について 行われてきた諸研究の概要は以下のとおりである。文献 (4) では各発電機の出力変化履歴を 5 分間隔でサンプリングし た時系列として扱い, 隣接 2 時点間の出力変化幅に注意し て各時刻ごとに負荷配分計算用の各発電機の出力上下限を 設定する方法を提案している。予め変化率制約を満たす範 囲を定めた上で等 $\lambda$ 法を用いることで文献(2)に比べて解 の feasibility（実行可能性）を高めることに成功している。 文献(5) は变化率制約等を含む経済負荷配分問題を非線形 最適化問題として定式化し, 確率的ニューラルネットワー クを用いてこれを解いている。文献 (6) もニューラルネッ トワークによる最適化であるが, 変化率制約や出力上下限 は，これに違反する時に大きな值をとるペナルティの形で 目的関数に含めた最適化を行っている。

一方，文献 (7) は，燃料費関数の係数が持つ不確実性を ファジィ数で表現するとともに, 最適化部分を遺伝的アルゴ リズムと組み合わせた計算法を提案している。文献 (8) は ファジィ動的計画法を用いてこの問題に対処しており，時 間軸方向に総和をとった目的関数の最小化を行っている。 これらに対して論文(9) では考察期間全体にわたる全対象 発電機燃料費総和を最小化するために制御時刻ごとに異な る $\lambda$ 值 (Lagrange 乗数) が導入されている。〈2・3〉節で後 述するとおり本論文でも $\lambda$ 值を時間変化する変数として取 り扱っているが，文献(9) は制御周期を時間間隔とする離 散時間系を導入, 制御周期時点ごとの最適化問題列として 定式化している点で異なる。本論文は連続時間系としての 定式化を行っており, 変分法に基づく微分方程式を解くこ とにより最適出力分担を時間の関数として求める。

著者らは既に論文(10)においてこの問題を連続時間系に おける変分問題として定式化し, Eulerの微分方程式によっ て火力機の出力変化率を考慮した最適化が可能であること を示した。たたし文献(10)では出力変化率の考慮はできる ものの, 出力上下限の考慮が不十分であり, 可能出力值の 幅が狭い場合には負荷配分が得られない場合が見られた。 このため本論文では文献(10)では使用しなかった対数障壁 関数（後出 Fig. 1) を目的関数に導入して不等式制約の考 慮を容易にするとともに, 出力可能範囲中央からの偏差を 二次関数によって表現した新しいペナルティ関数項を解の feasibility 向上のために目的関数に導入する。この結果, 実 行可能解を得ることが難しかった文献(9)の「パターン4」 (後出 Fig. 4) の需要変化など, 厳しい条件に対しても実行 可能解を算出することに成功した。

本論文では，まず第 2 章で問題の定式化について述べた 後, 第 3 章で計算アルゴリズムを提案し, 第 4 章で具体例 に適用して得られた結果を議論する。第 5 章は結論である。
なお, 本稿では経済性の観点で最も重要な発電燃料費に 焦点を絞り, 系統の潮流方程式は考慮しない。よって送電 損失は無視されるが, その大きさは通常, 発電出力に対し て 1 割以下であり，意志決定に大きな影響は与えない。

\section{2. 動的経済負荷配分問題の基本的考え方}

〈2・1〉文献 (9) における問題の定式化 既に前章で述 べたが本論文で提案する手法は文献 (9) が取り扱っているも のと同じ数值例に適用し, 比較・検討する。そこで文献 (9) における問題の定式化について説明する。

文献 (9) は文献 (11) 等と同様に, 火力発電機 $k$ の燃料費 はユニットごとに異なる係数 $a_{k}, b_{k}, c_{k}$ を用いて二次関数 の形で表している。時間軸方向は 5 分をサンプリング間隔 とする離散時間系として取り扱っており, 考察する時間範 囲 $(t=1,2, \ldots, T)$ 全体にわたっての燃料費総和を最小化 する。すなわち

$$
f=\sum_{t=1}^{T} \sum_{k=1}^{N}\left(\frac{a_{k}}{2} P_{k t}^{2}+b_{k} P_{k t}+c_{k}\right)
$$

が目的関数である。(1) 式の目的関数は時間の取り扱いが離 散時間系か連続時間系かという違いはあるにせよ, 以下に 述べる本論文の目的関数 (9) 式に非常に近い。これが本論 文で文献(9)を比較検討の対象に選んだ理由である。

制約条件としては，需給バランスに関する等式制約

$$
\sum_{k=1}^{N} P_{k t}=\hat{P}_{t}
$$

と, 出力上下限に関する不等式制約

$$
\underline{P_{k}}<P_{k t}<\overline{P_{k}}
$$

および変化率制約

$$
-\delta_{k} \leq P_{k t}-P_{k(t-1)} \leq \delta_{k}
$$

を考慮している。制約条件も本論文と類似の取り扱いであ るが, 離散時間系として取り扱うため, 後述する Eulerの 微分方程式は用いられていない。また本論文における時間 方向のサンプリング間隔は 1 分としており，この点でも取 り扱いが異なっている。

〈2·2〉 本論文における問題の定式化 本論文でも, 火 力発電機の燃料費は係数 $a_{i}, b_{i}, c_{i}$ を用いて次のように表 せるものと仮定する。

$$
f_{i}=a_{i}+b_{i} P_{i}+c_{i} P_{i}^{2}
$$

添え字 $i$ は第 $i$ 発電機 $(i=1,2, \ldots, \mathrm{NG}: \mathrm{NG}$ は発電機数 $)$ に関する量であることを意味し $, a_{i}, b_{i}, c_{i}$ の具体的な值 については文献(9) と同じく後出の Table 1 に示すように定 めた。同表には出力変化率の最大值 (増加側減少側とも同 一值）も併せて示す。本論文は系統を無視するため総コス トは各発電機に関する (5) 式のコストを加え合わせたもの, すなわち 


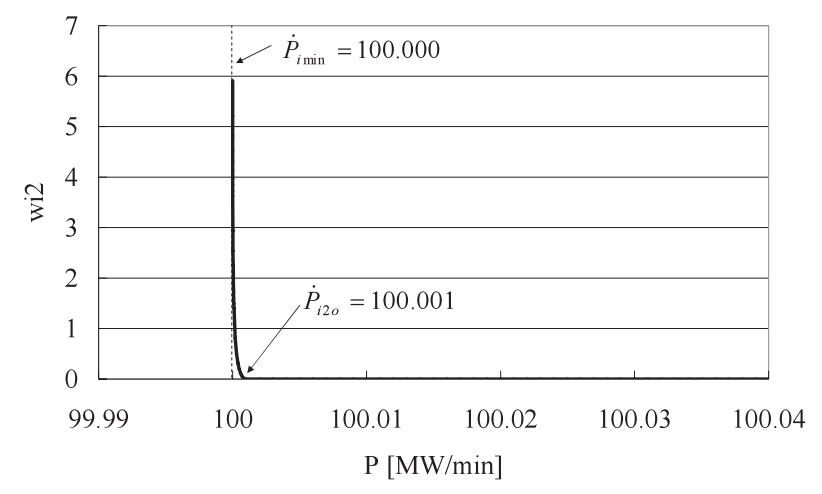

Fig. 1. Logarithmic penalty function.

$$
C=\sum_{i=1}^{N G} f_{i}=\sum_{i=1}^{N G}\left(a_{i}+b_{i} P_{i}+c_{i} P_{i}^{2}\right)
$$

となる。

各発電機の出力の和は需要の総和に等しい必要がある。 式で示すと, 総需要を表す時間関数を $P_{L}(t)$ として

$$
\sum_{i=1}^{N G} P_{i}(t)=P_{L}(t)
$$

となる。また各発電機の出力およびその变化率は次のとお り上下限で抑えられている。以下，傍点は時間微分を表す。

$$
\left.\begin{array}{l}
P_{i}(t) \geq P_{i, \min } \\
P_{i}(t) \leq P_{i, \max } \\
\dot{P}_{i}(t) \geq \dot{P}_{i, \min } \\
\dot{P}_{i}(t) \leq \dot{P}_{i, \text { max }}
\end{array}\right\}
$$

以上まとめると，本論文で扱うのは $\left(5^{\prime}\right)$ 式の燃料費モデ ルを元に (6), (7) 式の制約を満足しながら燃料費を最小化 する問題である。ただし，本論文では $\left(5^{\prime}\right)$ 式の代わりに次 の $\left(5^{\prime \prime}\right)$ 式に関する最小化を(6) 式のみの制約の元で行う。

$$
\begin{aligned}
f_{i}= & a_{i}+b_{i} P_{i}+c_{i} P_{i}^{2}+w_{i 1}\left(\dot{P}_{i}\right)+w_{i 2}\left(\dot{P}_{i}\right) \\
& +w_{i 3}\left(P_{i}\right)+w_{i 4}\left(P_{i}\right)+A\left(P_{i}-P_{i m}\right)^{2}
\end{aligned}
$$

ここで新しく加わっている第 4～5 項は変化率制約に関 するペナルティ，同様に第 6〜7 項は出力上下限に対する ペナルティであり，第 8 項は出力範囲中央からのずれに関 するペナルティである。4７項の具体的な関数形は次に示 す (8) 式で表される。ここで $\dot{P}_{i 1 o}, \dot{P}_{i 2 o}$ および $P_{i 1 o}, P_{i 2 o}$ は それぞれ第 $\mathrm{i}$ 発電機の変化率制約および出力上下限に関す る対数障壁関数の形状を決定するパラメータであり, Fig. 1 に示すように，これより内側ではペナルティ関数はゼロと なり，ここから急激に立ち上がり，上下限值に近づくにつ れ無限大のペナルティ值をとる。また $\dot{P}_{i 1 o} ， \dot{P}_{i 2 o}$ 等におい てペナルティ関数值およびその微分值は連続である。

$$
\begin{aligned}
& w_{i 1}(x)=\left\{\begin{array}{cc}
0 & \left(x \leq \dot{P}_{i 1 o}\right) \\
- & \ln \left(\frac{x-\dot{P}_{i \max }}{\dot{P}_{i 1 o}-\dot{P}_{i \max }}\right)-\frac{x-\dot{P}_{i 1 o}}{\dot{P}_{i \max }-\dot{P}_{i 1 o}} \\
\left(x>\dot{P}_{i 1 o}\right)
\end{array}\right. \\
& w_{i 2}(x)=\left\{\begin{array}{cc}
0 & \left(x \geq \dot{P}_{i 2 o}\right) \\
-\ln \left(\frac{x-\dot{P}_{i \min }}{\dot{P}_{i 2 o}-\dot{P}_{i \min }}\right)-\frac{x-\dot{P}_{i 2 o}}{\dot{P}_{i \min }-\dot{P}_{i 2 o}} & \left(x<\dot{P}_{i 2 o}\right)
\end{array}\right\} \\
& w_{i 3}(x)=\left\{\begin{array}{cc}
0 & \left(x \leq P_{1 o}\right) \\
-\ln \left(\frac{x-P_{i \max }}{P_{i 1 o}-P_{i \max }}\right)-\frac{x-P_{i 1 o}}{P_{i \max }-P_{i 1 o}} & \left(x>P_{i 1 o}\right) \\
w_{i 4}(x)= & \left(x \geq P_{2 o}\right) \\
-\ln \left(\frac{x-P_{i \min }}{P_{i 2 o}-P_{i \min }}\right)-\frac{x-P_{i 2 o}}{P_{i \min }-P_{i 2 o}} & \left(x<P_{i 2 o}\right)
\end{array}\right.
\end{aligned}
$$

また $\left(5^{\prime \prime}\right)$ 式右辺最終項に含まれるパラメータ $P_{i m}$ は発電機 $i$ の出力範囲

$$
P_{i \min } \leq P_{i} \leq P_{i \max }
$$

の中点

$$
P_{i m}=\left(P_{i \min }+P_{i \max }\right) / 2
$$

を意味し, 係数 A は解の実行可能性を制御するパラメータ であり，求解の過程で調整する。

本来不等式制約で表される条件をペナルティ関数に置き 換えたため, $\dot{P}_{i 1 o}, \dot{P}_{i 2 o}$ は限りなく $P_{i \max }, P_{i \min }$ に近づけ る必要がある。本論文では特に断らない限り $\dot{P}_{i 1 o}$ は上限值 $\dot{P}_{i \max }$ よりも $0.001 \%$ 小さく選び, この $0.001 \%$ 分と同一の大 きさの幅を下限值 $\dot{P}_{i \min }$ と $\dot{P}_{i 2 o}$ の間にも設けている。 $\dot{P}_{i 1 o}$, $\dot{P}_{i 2 o}$ を $\dot{P}_{i \max }, \dot{P}_{i \min }$ に近づけた場合に, 一般には非線形性の 影響で収束性が悪化する可能性が考えられるが，後に述べ る数值検討の結果, 収束性が悪化することは見られなかっ た。なお，ここで述べたことは全て出力変化率だけでなく， 出力上下限についても同様である。

最小化する目的関数について述べる。通常の経済負荷配 分問題では $\left(5^{\prime}\right)$ 式を各時点において最小化するが, 対象と する時間帯全体にわたっての発電費用を最小化することが できれば目的は達せられるので，この代わりに

$$
J[\mathbf{P}]=\int_{t_{1}}^{t_{2}} \sum_{i} f_{i}(t) d t=\int_{t_{1}}^{t_{2}} f(t) d t
$$

を最小化することを考える。つまり, 通常, 従来法では各 時点における発電量ベクトル

$$
\mathbf{P}=\left(\begin{array}{llll}
P_{1} & P_{2} & \cdots & P_{N G}
\end{array}\right)^{T}
$$

を別々の問題として最適化する場合が多いのに対して，提 案法は時間関数としての発電量波形ベクトル 


$$
\mathbf{P}(t)=\left(\begin{array}{llll}
P_{1}(t) & P_{2}(t) & \cdots & P_{N G}(t)
\end{array}\right)^{T}
$$

を関数として最適化する。なお既に述べたが，目的関数を 構成する各要素は $\left(5^{\prime \prime}\right)$ 式の形をしており，(6) 式の等式制 約条件を満たす必要がある。

また，本論文では特に需要変化の激しい昼休み等の時間 帯を対象に負荷配分を行うことを前提とする。考察期間は 3 時間程度とし, 文献(9)で用いている数值例がそうである ように，3時間の考慮期間の最初と最後では需要が一定レ ベルに落ち着く（後出 Fig. 4 を参照）ことを前提とする。

$\langle\mathbf{2} \cdot \mathbf{3}\rangle$ 変分法と提案法の概要 変分法の知識による と付録 1 に示すように (10)の沉関数は Euler の方程式を解 くことによって最小化することができる(12) (14)。ここで考 えている問題では付帯条件は (6) 式の代数方程式（発電機 出力総和が総需要に等しいとする) なので具体的に書くと

$$
\begin{aligned}
& \frac{\partial f}{\partial P_{i}}-\frac{d}{d t}\left(\frac{\partial f}{\partial \dot{P}_{i}}\right)+\lambda=0 \\
& \sum_{i=1}^{N G} P_{i}(t)=P_{L}(t) \cdots \cdots \cdots
\end{aligned}
$$

である。 $\lambda$ は (2) 式の制約条件に対応する Lagrange 乗数で あり，時間 $t$ の関数である。(11) 式の微分方程式の具体的 な形は付録 2 に示す。ここで得られた微分方程式(11) は付 録 2 に述べたように時間方向に数值積分することで解くこ とができるが，いかなる初期条件あるいは境界条件を用い るべきかについて検討する。

提案法の詳細は次章で述べるが，その概略を Fig. 2 に示 す。横軸 (時間軸) 方向両端の $t_{1}$ と $t_{2}$ の間が対象時間範囲 であり，この間の任意の時点で縦軸（発電機出力值）方向 に出力の取りうる範囲が決まる。Fig. 2 の上部下部にある 太い縦線を施した領域は出力が取り得ない範囲である。出 力上下限が時刻に応じて変わらなくとも，総需要の大きさ が時々刻々変化するために実際に出力の取りうる範囲は変 化する。たとえば後出の数值例で時刻 $t=115 \mathrm{~min}$ では総 需要が $350 \mathrm{MW}$ と非常に小さくなるので，発電機 $1,2,3$ はそれぞれの最小值 $100 \mathrm{MW}, 50 \mathrm{MW}, 200 \mathrm{MW}$ を取らざ るを得ない。

本論文で考える問題とは, Fig. 2 の可能領域 (feasible region）の中に, 燃料費が最小になるように発電機出力の変 化を表す曲線を引くことである。この際，変化率制約も考 慮するのであるから，曲線の傾きはこれ以内にしなければ ならない。次節にも述べるが，提案法は解の feasibility を 重視するので最も実行可能領域の狭い時刻を特別にとりあ げ，まず，この時点において確実に解を feasible とする。具 体的には, 出力值の変動可能幅の最も小さい時刻 $t_{o}$ を探し, ここを数值積分の始点に選び (Fig.2の 1)), その可能領域 の中央に出力值を定める (Fig. 2の 2))。始点 $t_{o}$ では各発電 機の出力值はこの值に固定されることになり, 付録 1 に述 べた固定境界条件となる。また $t_{o}$ での出力変化率はゼロと 指定する (Fig. 2 の 3) を参照)。ここで右側微分值と左側

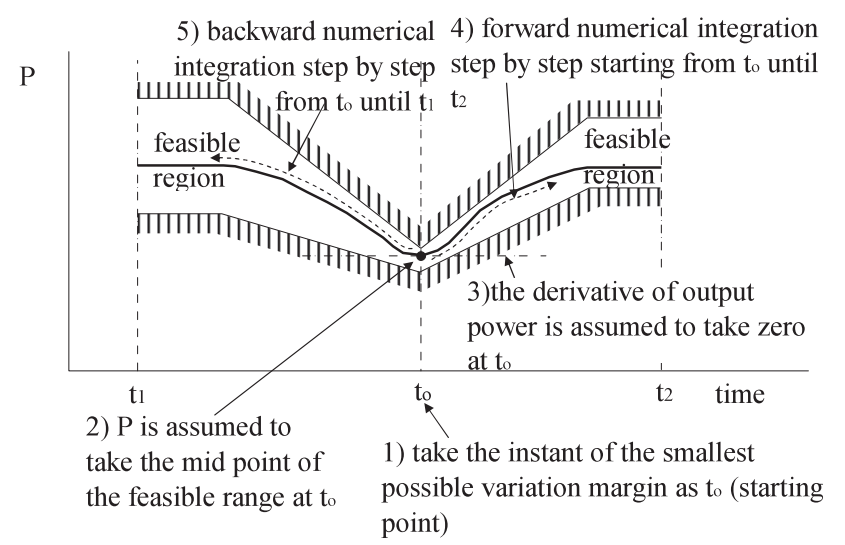

Fig. 2. Numerical integration in the proposed method.

微分值は等しく角点ではないとする。これにより $t_{o}$ では出 力上下限と変化率制約の両方が満たされる。

付録 2 で述べたように，提案法で解く微分方程式は出力 に関する 2 階の方程式であるから, 以上のように出力とそ の変化率を始点で与えれば初期条件は一意に定まり, Fig. 2 の $t_{o}$ から右へと（つまり順時間方向に）数值積分を行うこ とができる（Fig.2の 4)）。

一方, $t_{1}$ から $t_{o}$ までの範囲 (Fig. 2 の対象時間範囲の前 半)についても, やはり初期条件が一意に決まっているので 逆時間方向に数值積分を進めることができる Fig. 2 の 5))。

最後に終点（順時間方向積分では $t=t_{2}$, 逆時間方向積分 では $\left.t=t_{1}\right)$ においては特に出力を固定する必要はないの で，解の最適性の条件は付録 1 に述べた自然境界条件すな わち (9) 式被積分関数 $f$ を出力変化率 $\dot{P}_{i}$ で偏微分した值に ついての条件 (付 13) 式が満たされなければならない。こ れについてはく3・3〉節において述べる。

$\langle\mathbf{2} \cdot \mathbf{4}\rangle$ 計算の前提と提案法のねらい 動的経済負荷 配分問題では対象とする問題の前提条件によって用いるこ とのできる初期条件や入力データが左右される。たとえば 文献 (2) は将来時点の需要予測值を出発点として逆時間方 向に発電機の出力をまず計算し, これでは需給バランスが 満足できない場合に順時間方向の再配分を行っている。対 象時間範囲の需要が既に推定されていることを仮定してい る。一方, 文献(9) は一時刻前の経済負荷配分計算によっ て数時点先までの出力分担が分かっていることだけを前提 に現時点での意思決定をどうするかを論じ, 時間の経過と ともに需要想定が変化した場合の調整を, これとは切り離 して考察している。

本論文では, 対象とする時間範囲の需要が予め推定でき ていることを前提とし, 制約条件を全て満たすこと（すなわ ち実行可能解) を条件として, できるかぎり経済的な負荷配 分法を求めることを目指す。また，初期時点として選んた 時刻における各発電機の出力とその時間変化率は分かって いるものとする。本論文では, これまで種々の方法が試さ れても完全に需給バランスをとることの難しかった文献(9) の「パターン 4」（後出 Fig. 4）において実行可能解を算出 
することをねらう。

これにより，解くべき問題は初期条件

$$
\left.\begin{array}{rl}
\mathbf{P}\left(t_{1}\right) & =\left(\begin{array}{llll}
P_{1}\left(t_{1}\right) & P_{2}\left(t_{1}\right) & \cdots & P_{N G}\left(t_{1}\right)
\end{array}\right)^{T} \\
\dot{\mathbf{P}}\left(t_{1}\right) & =\left(\begin{array}{llll}
\dot{P}_{1}\left(t_{1}\right) & \dot{P}_{2}\left(t_{1}\right) & \cdots & \dot{P}_{N G}\left(t_{1}\right)
\end{array}\right)^{T}
\end{array}\right\} \cdots \cdots
$$

のもとで，沉関数 (9) 式を最小化するように等式制約条件 $\left(6^{\prime}\right)$ 式を満たす時間関数べクトル (10) 式を決める関数最適 化問題となる。

本論文では提案手法の妥当性を示すため, 文献 (9) で用 いられている例題に適用し, 文献 (9) の計算結果と比較す る。これはく2・1〉節にも述べたように, 最適化問題として の定式化に扔ける目的関数が，時間の取り扱いが若干異な るだけで非常に近く，かつ制約条件も実質的に同一である ため，比較の対象としやすいことによる。

\section{3. 提案手法}

〈3.1〉 静的経済負荷配分 動的経済負荷配分を計算 する前に，まず一度発電機出力変化率制約を無視した等 $\lambda$ 法による静的負荷配分計算を行い，得られた負荷配分曲線 をチェックする。もしも全ての発電機の出力変化率が対象 とする全時間範囲で制約範囲内に収まっていたら，動的負 荷配分を計算する必要はなく，これを解とする。

発電機の出力变化率に制約違反が生じていた場合に，以 下の動的負荷配分を行う。

〈3.2 $\rangle$ 初期点の選択 数值積分の出発点となる時刻 $t=t_{o}$ （Fig. 2）について考察する。動的負荷配分問題の解 ベクトル $P(t)$ が存在しうる領域は静的負荷配分問題にお いて得られる $P(t)$ の存在領域の内部にあるのは明らかであ る。極端な例として, 静的負荷配分問題の実行可能解が時 刻 $t=t_{o} に$ にいて，ただ一点に定まる場合には，動的負荷配 分問題の解も，必ずこの一点を通るはずである。従って解 の feasibility を重視する提案法では, 前段で行う静的最適 負荷配分の結果得られた解曲線の軌道上各点で静的制約を 満たす解の範囲を求め, 最も範囲が狭い点を初期点に選ぶ。

具体的には任意の時点 $t$ に抒いて求められた静的最適負

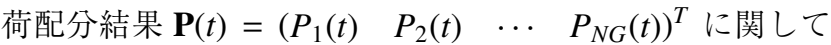
発電機ごとの出力増加可能量ベクトル

$$
\begin{aligned}
\Delta_{+} \mathbf{P}(t) & =\left(\begin{array}{llll}
\Delta P_{1}(t)_{+} & \Delta P_{2}(t)_{+} & \cdots & \Delta P_{N G}(t)_{+}
\end{array}\right)^{T} \\
& =\left(\begin{array}{llll}
P_{1 \max }-P_{1}(t) & \cdots & P_{N G \max }-P_{N G}(t)
\end{array}\right)^{T}
\end{aligned}
$$

と, 出力減少可能量ベクトル

$$
\begin{aligned}
\Delta_{-} \mathbf{P}(t) & =\left(\begin{array}{llll}
\Delta P_{1}(t)_{-} & \Delta P_{2}(t)_{-} & \cdots & \Delta P_{N G}(t)_{-}
\end{array}\right)^{T} \\
& =\left(\begin{array}{lll}
P_{1}(t)-P_{1 \text { min }} & \cdots & P_{N G}(t)-P_{N G \text { min }}
\end{array}\right)^{T}
\end{aligned}
$$

を計算し，増加，減少それぞれの要素の総和のうち小さい ほうの大きさ $M$ (Margin) を

$$
M=\min \left(\sum_{i} \Delta P_{i}(t)_{+}, \sum_{i} \Delta P_{i}(t)_{-}\right)
$$

により計算，時点 $t$ ごとに比較し，これが最小となる時刻 $t$ を動的負荷配分のための初期点 $t_{0}$ として選択する。

$\langle\mathbf{3} \cdot \mathbf{3}\rangle$ Euler の方程式の数值積分 以上で定めた初期 点 $t=t_{o}$ から出発し, 微分方程式を数值的に解いていく。 数值積分の手法としては安定性の高い後退オイラー法を用 いることとし，

$$
\left.\begin{array}{rl}
Q(t) & \equiv \dot{P}(t)=(P(t)-P(t-\Delta t)) / \Delta t \\
\dot{Q}(t) & =(Q(t)-Q(t-\Delta t)) / \Delta t
\end{array}\right\} .
$$

により代数化した方程式を等式制約 $\left(6^{\prime}\right)$ 式すなわち

$$
P_{1}(t)+P_{2}(t)+\cdots P_{N G}(t)=P_{L}(t) \cdots
$$

と連立して, まず順時間方向に時刻 $t=t_{0}+\Delta t, t_{0}+2 \Delta t, \ldots, t_{2}$ について解く。時間刻みは, 扱っている問題が ELDであり 制御対象が十数分程度の，ある程度長い時間の現象である ため過度に細かくとる必要はなく，一分程度で十分である。

この連立方程式はぺナルティ関数を対数関数にしている ため非線形である。本論文ではニュートン法によって解い た。ここで解いている方程式の具体的な形を付録 3 に示す。

なお，初期時点として選んだ $t=t_{0}$ が計算対象となる時 間区間 $t_{1} \leq t \leq t_{2}$ の最初の時点 $t=t_{1}$ に一致しないかぎ り, 数值積分は順方向だけでなく逆方向にも行う。逆方向 の数值積分は時間刻み $\Delta t$ を負として $t=t_{1}$ まで同様に計算 する。

$\langle 2 \cdot 3\rangle$ 節と付録 1 に述べたように, 終点 $t=t_{1}$ および $t=t_{2}$ では本来自然境界条件すなわち (9) 式の被積分関数 $f$ を出力変化率 $\dot{P}_{i}$ で偏微分した值についての条件 (付 13) 式 が満たされなければならない。具体的には

$$
-2 c_{i} \ddot{P}_{i}-d w_{i 1}\left(\dot{P}_{i}\right)-d w_{i 2}\left(\dot{P}_{i}\right)=0 \cdots
$$

である。しかし，提案法では〈2・2〉節最後に述べたように， 対象時間範囲の始点㧍よび終点で需要と発電機出力が一定 レベルに落ち着くことを前提としている。このためこの時 出力変化率はゼロで一定となり, $\ddot{P}_{i}=0$ かつ $d w_{i 1}$ と $d w_{i 2}$ はいずれもゼロとなり (付録 2 の (付 15) 式を参照)，これら の点で成立すべき (16) 式は満足されるものと予想される。

このため数值積分においては取り扱うのが難しい二点境 界值問題として定式化する必要はなく, 固定境界である始点 において, その後の計算が可能になるよう, 出力值と出力変 化率の双方を与え，数值積分を実行する。ただし，このうち 出力変化率については与え方に任意性があるので, 結果に及 ぼす影響を議論する必要がある。これについてはく4・4〉節 において述べる。

$\langle\mathbf{3} \cdot \mathbf{4}\rangle$ パラメータ $\boldsymbol{A}$ の調整 既出 $\left(5^{\prime \prime}\right)$ 式の右辺第 8 項は解が出力可能領域の中心からずれると徐々に大きな值 をとるペナルティ関数であり，係数 $A$ をゼロとした場合が 本来の意味での燃料費最適化に対応する。しかし最適性の みを考慮するのでは，本論文で対象とするような厳しい条 件には実行可能解が求められない場合がある。このため $A$ の值を次第に大きくして方程式を解き，解が制約を满たす 


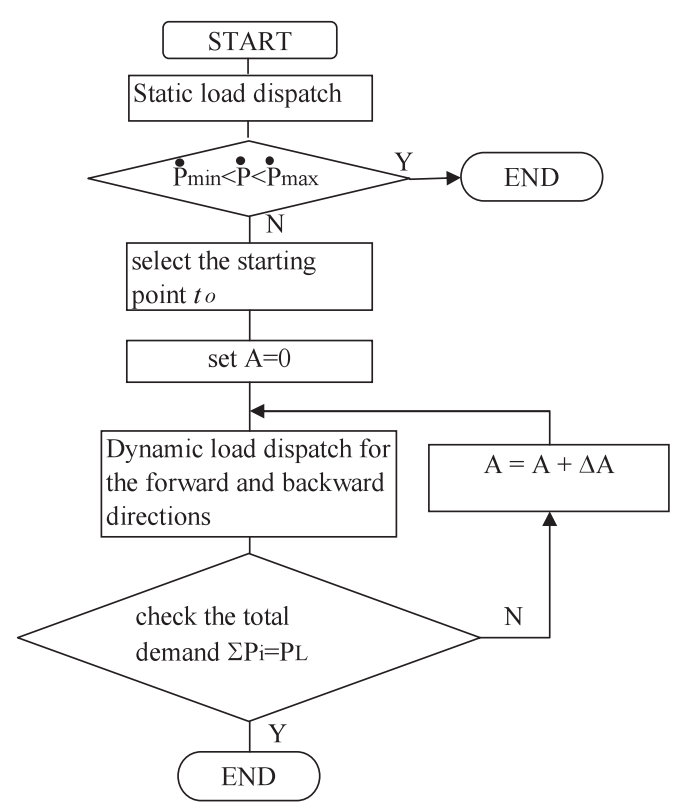

Fig. 3. Flow chart of the proposed method.

\section{ように調整を行う。}

大きな $A$ を与えすぎると得られる解の最適性が必要以上 に損なわれる可能性があるので， $A$ 值の調整は注意深く行 う必要がある。本論文では予め定めたステップ幅 $\Delta A$ で増 加させた。次章数值例では $\Delta A=0.1$ としている。

以上述べた提案法の計算手順を Fig. 3 に示す。

\section{4. 数 值 例}

$\langle\mathbf{4} \cdot \mathbf{1}\rangle$ 計算条件 既に述べたが，本論文では文献 (9) で取り扱われている需要変化パターン「パターン4」を題材 にして提案手法の妥当性を検証する。文献 (9) に述べられ ているように，このパターンは昼休みに打ける急激な火力 発電機群の出力制限と午後最初の出力の急増を表現するも ので, 従来の動的負荷配分手法の研究において完全な需給 バランスをとるのは非常に難しいとされてきた。Fig. 4 に パターン 4 の需要変化シナリオを示す。また, 計算に用い る発電機の燃料費データも文献(9) と共通としている。こ れらを Table 1 に示す。

$\langle\mathbf{4} \cdot 2\rangle$ 数值計算結果 Fig. 5 は静的最適経済負荷配分 の結果である。需要の小さい $t=115 \mathrm{~min}$ 付近では各発電 機の出力が下限ぎりぎりまで絞られるが, 需要が大きくな るにつれて (Fig. 5 で $t=115 \mathrm{~min}$ から左右にずれるにつれ て), 最初は最もコストの安い発電機 3 , 次いで発電機 2 , 1 の順に出力が分担され，この結果，どの時点でも発電機 1，2，3のうち，いずれか一機のみの出力が変化している。 Fig. 4 に示した需要変化では $t=110 \sim 120 \mathrm{~min}$ の間を除き 出力変化率は $10.8 \mathrm{MW} / \mathrm{min}$ と大きいため, いずれの発電 機も自身の出力変化率として許される上限值を超えて出力 を変化する結果となり, Fig. 5 の出力変化は実行可能では ない。

$\langle 2 \cdot 3\rangle$ 節，〈3·2〉節で述べたように，提案法では静的負

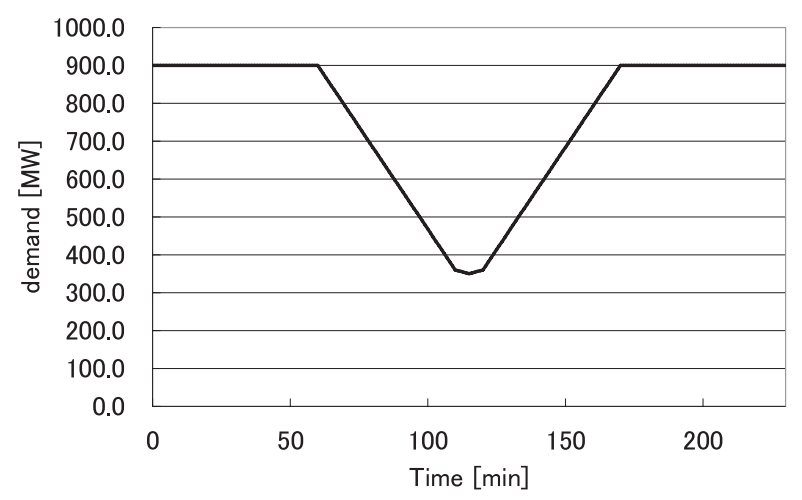

Fig. 4. Demand variation pattern 4.

Table 1. Input data.

\begin{tabular}{l|l|l|l}
\hline & Gen. Unit 1 & Gen. Unit 2 & Gen. Unit 3 \\
\hline $\mathrm{a}[$ yen] & 15.0 & 10.0 & 5.0 \\
\hline $\mathrm{b}[\mathrm{yen} / \mathrm{MW}]$ & 7.5 & 5.0 & 2.5 \\
\hline $\mathrm{c}\left[\mathrm{yen} / \mathrm{MW}^{2}\right]$ & 0.002 & 0.0015 & 0.001 \\
\hline $\min \mathrm{P}[\mathrm{MW}]$ & 100.0 & 50.0 & 200.0 \\
\hline $\max \mathrm{P}[\mathrm{MW}]$ & 300.0 & 250.0 & 400.0 \\
\hline $\max \mathrm{dP} / \mathrm{dt}$ & $7.0 \mathrm{MW} / \mathrm{min}$ & $3.0 \mathrm{MW} / \mathrm{min}$ & $5.0 \mathrm{MW} / \mathrm{min}$ \\
\hline
\end{tabular}

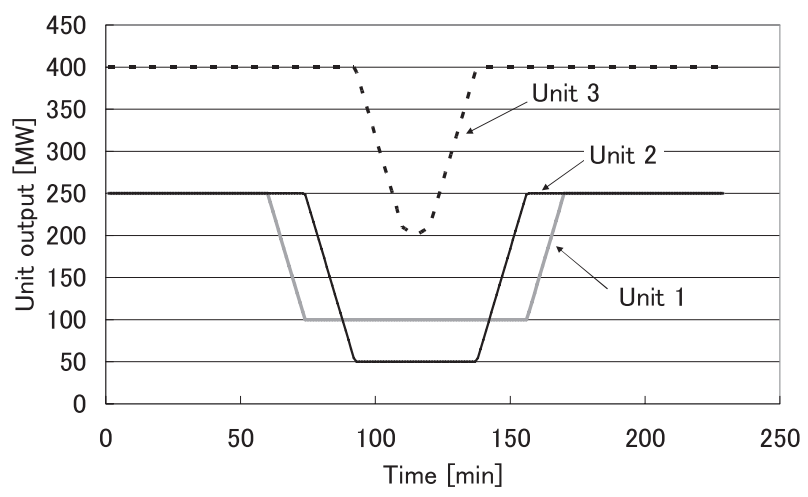

Fig. 5. Result of static ELD.

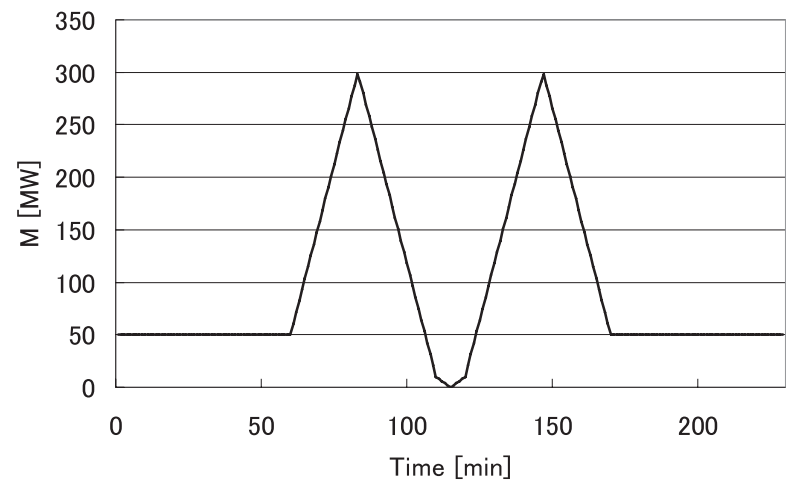

Fig. 6. Shape of function $M$.

荷配分結果をもとに動的負荷配分計算の初期点 $t_{0}$ を選ぶ。 このために (13) 式の $M$ 值を計算した。結果を Fig. 6 に示 す。 $M$ が最小となるのは $t=115 \mathrm{~min}$ であり, この点を初 期点に選ぶ。

この点を初期点に選んで数值積分を行った。〈3·3〉節に 


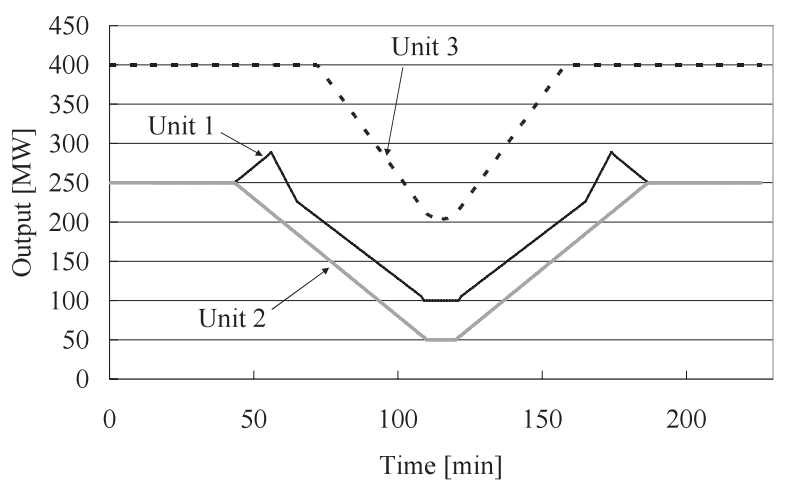

(a) Outputs variation

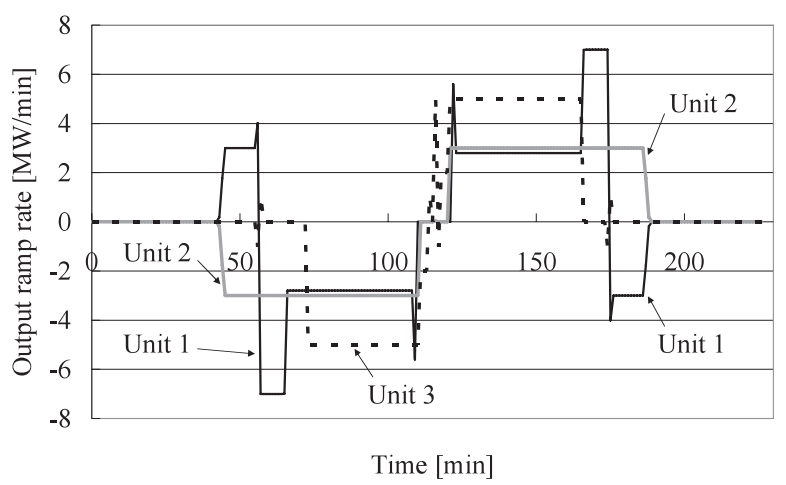

(b) Output ramp rate variation

Fig. 7. Result of proposed method $(A=0)$.

述べたように初期点の出力変化率は全てゼロとした。解の 実行可能性を制御するパラメー夕Aはここではゼロである。 この時にはく4・3〉節で後述するように後退オイラー法数值 積分を実行する際の Newton 法が収束せず，解を得ること ができなかった（Fig. $12 に t=170 \mathrm{~min} に$ におる残差の推 移を示す)。Newton 法の1000 回の繰り返しの中で最も残 差が小さい点を近似解として強引に計算を継続したところ, 近似的な解が得られた。得られた結果を Fig. 7 に示す。

Fig. 7 に示す波形では全ての発電機の出力変化率と出力 は制約内部に収まっている。また, 最低需要の $t=115 \mathrm{~min}$ から需要が増えるにつれて, 最初は最もコストの安い発電 機 3 のみ，次に発電機 3 の出力変化率を最大にした上でコ ス卜中位の発電機 2 の変化率を最大にし，これで賄えない部 分を最も費用性能の劣る発電機 1 に分担させる結果となっ ている。最後に発電機 1 の出力が一旦上昇した後減少して いるのは, 需要とともに増加させてきた発電機 3 (最安) の 出力が $t=158 \mathrm{~min}$ で上限 $400 \mathrm{MW}$ に達したため, 発電機 2 の変化率制約による出力不足を発電機 1 に分担させて賄 い，その後出力一定の定常状態に打ける最適分担（これは 静的計算によっても知られる) に合わせるように，残り 2 機のうちコスト優位の発電機 2 の出力をできるかぎり増や すため，余分な出力を発電機 1 に扔いて調整した結果であ る。この結果は完全には方程式が解けていないながらも, 各時点の出力值が，その時点で利用可能な発電機出力余力 を用いて，最も費用の安い組み合わせを実現していると理

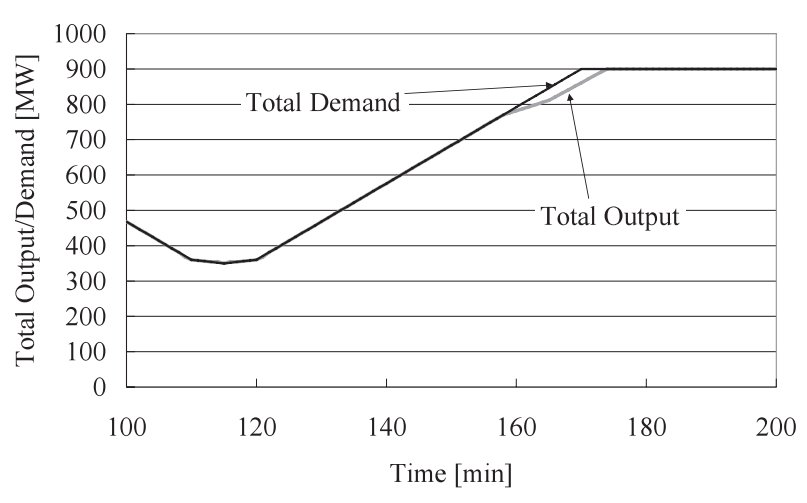

Fig. 8. Mismatch between supply/demand $(A=0)$.

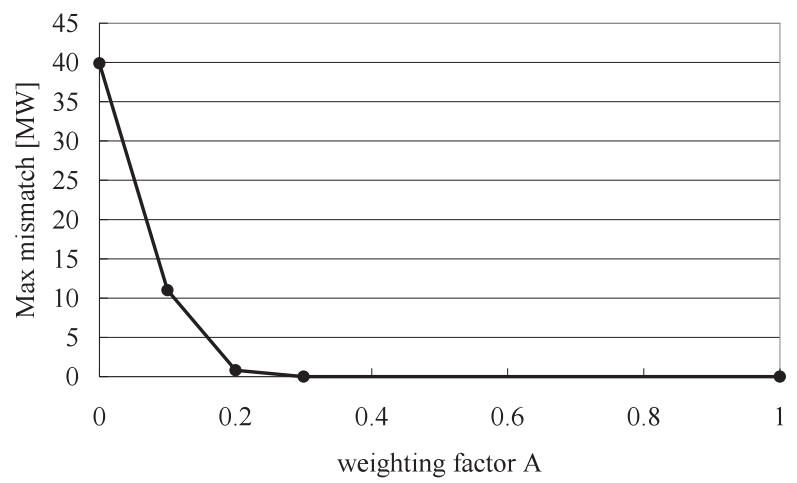

Fig. 9. Obtained maximum mismatch for various $A$.

解できる。

結果として得られる総発電量は Fig. 8 のように推移して おり , 時刻 $t=60 \mathrm{~min}, 170 \mathrm{~min}$ 付近で最大 $40 \mathrm{MW}$ 程度の 需給不均衡が生じており, 実行可能ではない。文献 (9)でも 量は $10 \mathrm{MW}$ と提案法よりも小さいが需給不均衡を生じて いる。次に需給不均衡を解消するためにパラメータ $A\left(\left(5^{\prime \prime}\right)\right.$ 式右辺第 8 項の係数）を調整した。この時に得られた結果 での需給不均衡量の大きさを Fig. 9 に示す。 $A$ を大きくす ることによって Fig. 8 で生じていた需給不均衡は急速に解 消している。なお，この時に得られた発電ユニットごとの 出力変化は Fig. 10 のとおりであり, Table 2 に $A=0.3$ の 時の出力変化を要約するが, 全時間範囲にわたって制約条 件範囲内に収まっている。つまりこれは実行可能解である。 Fig. 7 と比較すると費用の安い発電機 3 の出力レベルが落 ち, 費用の高いユニット 2 や 1 の利用量が増している。こ れは経済性の面で好ましくない。Table 3 に各 $A$ 值で得ら れた発電ユニット運用における総発電費用を示す。最大で 約 3\%の差が見られる。

以上のように, 提案法はここで仮定した需要変化パターン に対して有効に働き，実行可能解を算出することができる。 文献 (9) とは結論が異なるが，この理由の一つは〈2・1〉節 で述べたサンプリング間隔の違いであると考えられる。

$\langle\mathbf{4} \cdot \mathbf{3}\rangle$ 収束性の検討 本手法は数值積分において二 ユートン法を用いているため, 収束性が重要である。そこで 本節では $A=0.3$ の場合を中心に収束性を検討する。Fig. 11 
関数最適化による動的経済負荷配分法

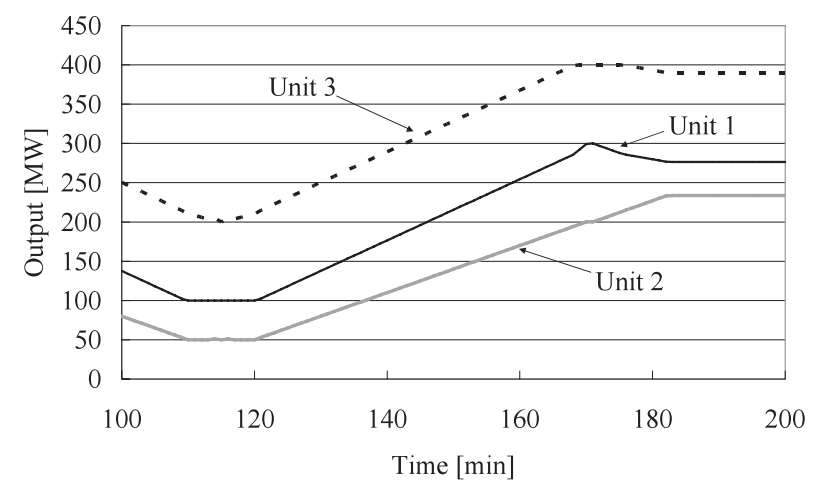

(a) $A=0.1$

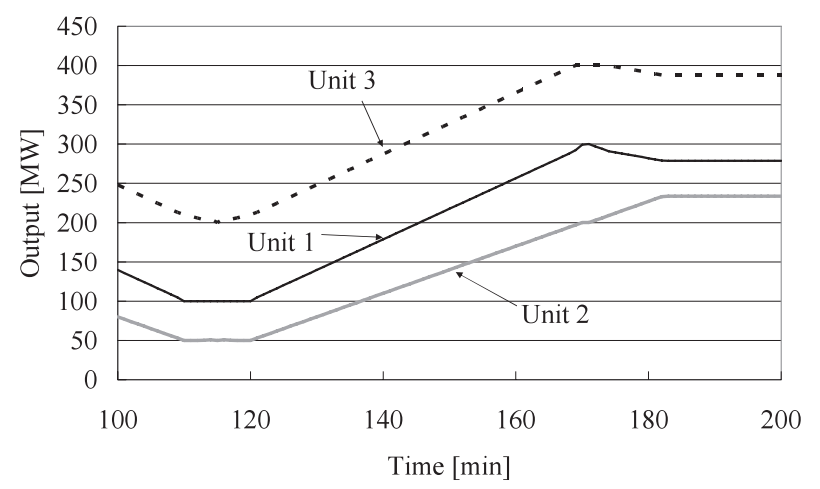

(b) $A=0.3$

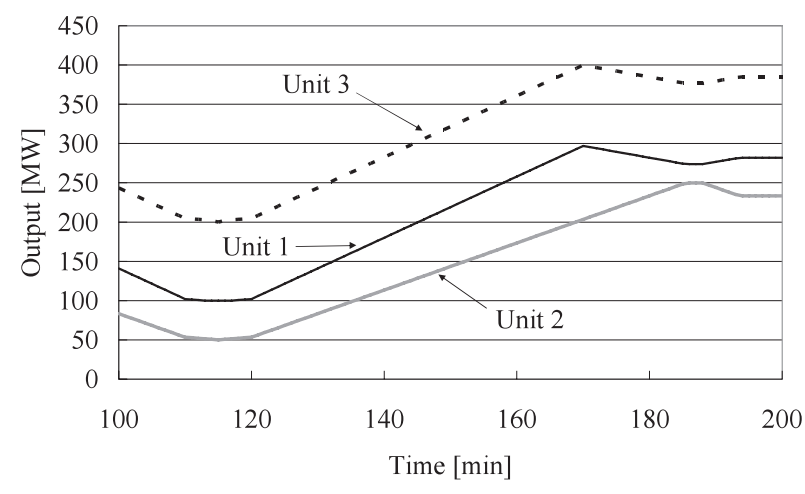

(c) $A=1.0$

Fig. 10. Results of proposed method for different $A$.

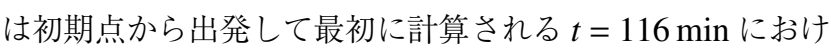
る収束状況である。縦軸は解いている連立方程式 (付 17)の 残差平方和 $\sum \Delta g_{i}^{2}$ を初期值で割った相対值であり, Fig. 11 中の ALPHA はニュートン法の減速乗数 $\alpha$ （下式）である。

$$
\left.\begin{array}{l}
x=x+\alpha \Delta x \\
\Delta x=[J]^{-1} \Delta g
\end{array}\right\}
$$

ここで $x=\left[\begin{array}{lllll}P_{1}(t) & Q_{1}(t) & \cdots & Q_{N G}(t) & \lambda(t)\end{array}\right]^{T}$ は付録 3 の未知数べクトル, $\Delta g$ は (付 17) 式に示す連立方程式の残 差べクトル，Jは (付 18) 式のヤコビ行列である。

$\alpha$ が大きい場合には相対的に毎回の修正量が大きいため, 非線形性および不等式制約条件の影響によって時折残差が 大きくなることがあるが，全体的には収束は良好である。 $\alpha$ が小さい場合には，あまり非線形性の影響も受けず，振 動的にもならずに収束する。実行可能性に関する重みパラ
Table 2. Resultant output pattern in case of $A=0.3$.

\begin{tabular}{|c|c|c|c|c|c|c|}
\hline time & \multicolumn{2}{|c|}{ Unit 1} & \multicolumn{2}{|c|}{ Unit 2} & \multicolumn{2}{|c|}{ Unit 3} \\
\hline [min] & [MW] & [MW/min] & [MW] & {$[\mathrm{MW} / \mathrm{min}]$} & {$[\mathrm{MW}]$} & {$[\mathrm{MW} / \mathrm{min}]$} \\
\hline \multirow{2}{*}{$\sim 49$} & 278.75 & & 233.60 & & 387.64 & \\
\hline & & 0.25 & & -0.49 & & 0.25 \\
\hline \multirow[t]{2}{*}{50} & 279.00 & & 233.11 & & 387.89 & \\
\hline & & $1.50 \sim 3.00$ & & -3.00 & & $0 \sim 1.50$ \\
\hline \multirow[t]{2}{*}{60} & 296.93 & & 203.11 & & 399.96 & \\
\hline & & -6.85 & & -3.00 & & -0.95 \\
\hline \multirow[t]{2}{*}{61} & 290.08 & & 200.11 & & 399.01 & \\
\hline & & $3.15-3.89$ & & -3.00 & & $-3.91 \sim-4.65$ \\
\hline \multirow[t]{2}{*}{110} & 100.03 & & 53.11 & & 206.86 & \\
\hline & & 0.0 & & $\begin{array}{c}-0.09 \sim \\
-1.00\end{array}$ & & $-1.00 \sim-1.91$ \\
\hline \multirow[t]{2}{*}{114} & 100.03 & & 50.03 & & 201.94 & \\
\hline & & -0.03 & & -0.03 & & -1.94 \\
\hline \multirow[t]{2}{*}{115} & 100 & & 50 & & 200 & \\
\hline & & 0.03 & & 0.03 & & 1.94 \\
\hline \multirow[t]{2}{*}{116} & 100.03 & & 50.03 & & 201.94 & \\
\hline & & 0.0 & & $0.09-1.00$ & & $1.00-1.91$ \\
\hline \multirow[t]{2}{*}{120} & 100.03 & & 53.11 & & 206.86 & \\
\hline & & $3.15-3.89$ & & 3.00 & & $3.91-4.65$ \\
\hline \multirow[t]{2}{*}{169} & 290.08 & & 200.11 & & 399.01 & \\
\hline & & 6.85 & & 3.00 & & 0.95 \\
\hline \multirow[t]{2}{*}{170} & 296.93 & & 203.11 & & 399.96 & \\
\hline & & $\begin{array}{c}-3.00 \sim ~ \\
-1.50\end{array}$ & & 3.00 & & $0 \sim-1.50$ \\
\hline \multirow[t]{2}{*}{180} & 279.00 & & 233.11 & & 387.89 & \\
\hline & & -0.25 & & 0.49 & & -0.25 \\
\hline $181 \sim$ & 278.75 & & 233.60 & & 387.64 & \\
\hline
\end{tabular}

Table 3. Total generation cost for various $A$.

\begin{tabular}{c|c|c|c|c}
\hline $\mathrm{A}$ & 0.0 & 0.1 & 0.3 & 1.0 \\
\hline Total cost & 1.000 & 1.018 & 1.034 & 1.038 \\
\hline Figure & 7 & $10(\mathrm{a})$ & $10(\mathrm{~b})$ & $10(\mathrm{c})$ \\
\hline
\end{tabular}

$*$ cost is normalized by the case of $\mathrm{A}=0.0$

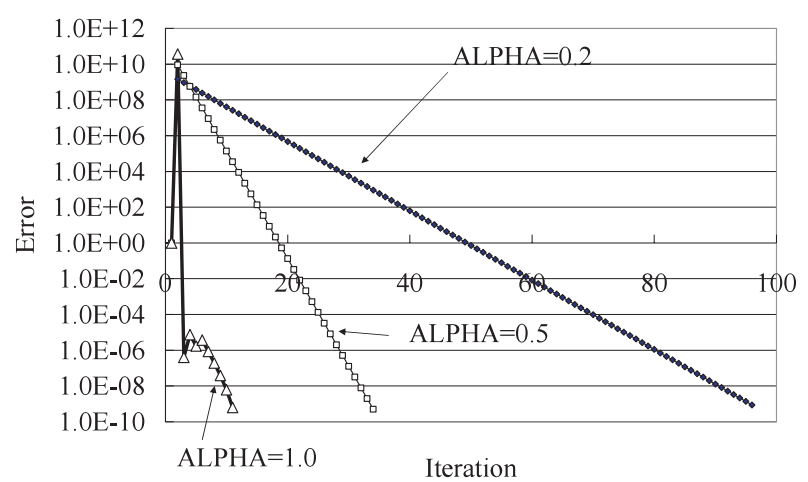

Fig. 11. Convergence at $t=116 \mathrm{~min}$.

メータ Aの值が違っても収束性にはほとんど影響せず，ほ ぼ同様の結果となった。

この傾向は求解する時間の全範囲でほぼ同様であったが, $\langle 4 \cdot 2\rangle$ 節で述べた需給不均衡が生じる時間領域では悪化し た。ここで解こうとする連立方程式は需給バランスに関す る等式を含んでいるが，この条件を満たしつつ目的関数を 最小化する解が存在しないためである。 $A=0.0$ の場合 は〈4・2〉節で述べたように反復収束計算が成功せず，強引 に求めた近似解（Fig. 7) にも Fig. 8 のように需給アンバラ 


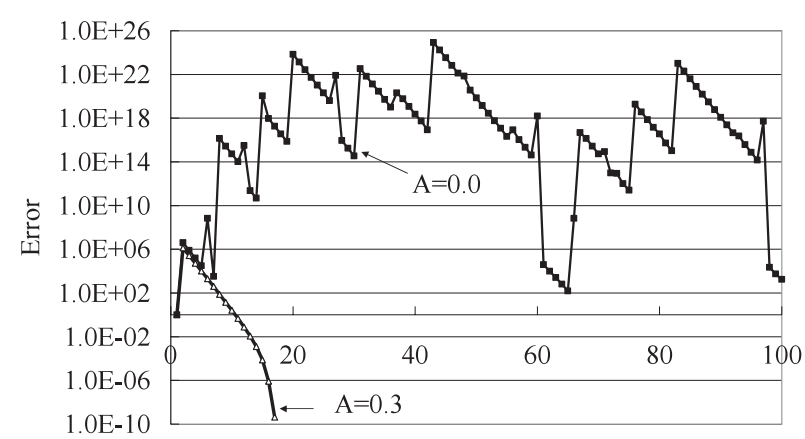

Iteration

Fig. 12. Convergence at $t=170 \mathrm{~min}$.

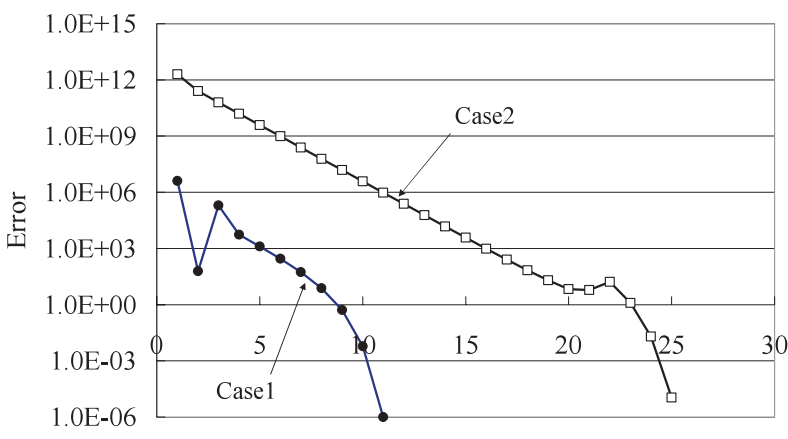

Iteration

Fig. 13. Effect of initial value setting.

ンスが生じていた。これはここで解こうとした連立方程式 が制約範囲内に解が持たなかったためである。Fig. 12 上部 は, $t=170 \mathrm{~min} に$ に扔ける反復収束計算過程で連立方程式の 残差平方和がどのように動いているかを示している。収束 する様子が見られないが，同図下部に示すように $A=0.3$ の場合には良好に収束していることが分かる。

$\langle\mathbf{4} \cdot \mathbf{4}\rangle$ 初期点出力变化率の設定の検討 本手法は (7) 式の微分方程式を(11) 式に示すように離散化して数值積分 するものであり，初期条件が解に影響を与える。〈4·2〉節 以降の計算結果は初期点の出力変化率を全てゼロと置いて 得たものである。〈2·3 節で述べたように $P_{i}$ に関する初期 值は条件から確定するが $Q_{i}$ (出力変化率) の初期值は不確 定であり，数值積分を行う都合上設定したものであるため， これをどのように設定するかが解に影響を及ぼさないか確 認する必要がある。初期点の影響を調べるので前節 Fig. 11 と同様に $t=116 \mathrm{~min}$ に注目した。

この結果を Fig. 13 に示す。図でケース 1 とは，これまで 行ってきたように

$$
Q\left(t_{0}\right)=\left.\frac{d P}{d t}\right|_{t=t_{o}}
$$

をゼロとした場合の収束状況であり，ケース 2 は前段であ る静的経済負荷配分結果を用いて,

$$
Q\left(t_{0}\right)=P\left(t_{0}\right)-P\left(t_{0}-\Delta t\right)
$$

とした場合である。ここで検討している数值例では $t=$
Table 4. Final value of Eq. (16) for the both cases (Check result of the natural boundary condition).

\begin{tabular}{c||c|c|c}
\hline & Unit 1 & Unit 2 & Unit 3 \\
\hline \hline Case 1 & $-5.68 \times 10^{-17}$ & $-4.26 \times 10^{-17}$ & $5.68 \times 10^{-17}$ \\
\hline Case 2 & $-6.01 \times 10^{-16}$ & $-8.53 \times 10^{-17}$ & $-3.41 \times 10^{-16}$ \\
\hline
\end{tabular}

115 min を境に需要が減少から増加に転じているので求解 対象の時間範囲ではユニット出力が増加する方向となるべ きであるにもかかわらず，ケース 2 では初期時点の出力変 化率が負であるため収束に必要な反復回数が増している。 しかし収束特性はケース 1 とあまりかわらず，ほぼ同様に スムーズに収束している。求められた出力の值を両ケース で比較すると，その相違は最大でも $1.0 \times 10^{-5} \mathrm{MW}$ 未満で あり，最も小さい場合でも考察時間範囲である 230 分の間 に発電出力は $200 \mathrm{MW}$ 程度変化していることを考えれば, 初期点での出力変化率 $\mathrm{Q}$ 值の設定による影響は非常に小さ く無視できるレベルであった。以上より，初期点の出力変 化率の設定は提案法の数值解法としての性能に大きな影響 を及ぼさないことが分かった。

なお，終点が満足すべき自然境界条件 (16) 式左辺值につ いても調べた。この結果を Table 4 に示すが，〈3·3〉節で 予想したとおりゼロとなっていることが確認される。これ は〈2.2〉節最後に述べた前提によるものである。論文冒頭 にも述べたと抢り変動電源の増大等の趨勢を考えると, 今 後必ずしもこの前提が常に成り立つものとは考えられない。 このようなケースでも終点での自然境界条件を満足させる には，提案法を拡張する必要があるが，これは今後の課題 とする。

\section{5. 結 論}

本論文では火力発電機の出力変化率制約を考慮する動的 経済負荷配分計算手法を提案した。提案法は出力上下限と 変化率制約を対数関数形のペナルティ関数として目的関数 に入れ込むもので，こうして得られる新しい目的関数を等 式制約を考慮して最小化する。ただし最小化に扔いて，予 め想定した時間範囲の積分值を扱うことによって変分法と して定式化し, Eulerの微分方程式を数值的に解くことで最 適な負荷配分を求める。

提案法では従来法に比べてより一層の実行可能解の求解 性を向上するために, 各発電機の出力可能範囲の中央から の逸脱量に関する 2 次関数形のペナルティを導入した。そ の重みを調節することで特に厳しい需要変化が見込まれる 場合の求解性能を高めた。

提案法を，これまでたびたび用いられてきた変化率の高 い厳しい需要想定パターンに適用した。その結果, 実行可 能解を算出することができ，有効性が確認された。

今後は規模の大きな問題に適用した場合の求解性能等に ついて検討を行いたい。

(平成 21 年 6 月 11 日受付, 平成 21 年 8 月 14 日再受付) 


\section{文献}

(1) T. Inoue: "MW Response of Thermal Power Plant from Viewpoint of Power System Frequency Control", IEEJ Trans. PE, Vol.124, No.3, pp.343-346 (2004-3) (in Japanese)

井上俊雄:「電力系統の周波数制御から見た火力機の出力応動特性」, 電学論 B, 124, 3, pp.343-346 (2004-3)

(2) H. Isoda: "On-line Load Dispatching Method Considering Load Variation and Response Capability of Thermal Units", IEEE Trans. PAS, Vol.PAS100, No.8, pp.2925-2930 (1982)

(3) N. Yorino, Y. Zoka, Y. Sasaki, and A. Sudo: "Dynamic Generation Dispatching Method for AGC for the System with a large amount of Unpredictable DG generation", 2009 National Convention Record IEE Japan, No.6-038 (2009) (in Japanese)

餘利野直人·造賀芳文・佐々木豊・須藤 文:「変動電源を含む系統 の需給バランス調整に適したダイナミック負荷配分法」, 平成 21 年 電気学会全国大会, No.6-038 (2009)

(4) Y. Kitauchi, N. Yorino, and Y. Tamura: "The On-line ELD Method with High Feasibility of Dispatching for Thermal Units", T. IEE Japan, Vol.107B, No.3, pp.131-138 (1987-3) (in Japanese)

北内義弘・餘利野直人・田村康男：「Feasibility の高いオンライン火 力機経済負荷配分法」, 電学論 B, 107, 3, pp.131-138 (1987-3)

(5) Y. Fukuyama and Y. Ueki: "An application of artificial neural network to dynamic economic load dispatching", Proc. of the First International Forum on Applications of Neural Networks to Power Systems, pp.261-265 (1991)

(6) R. Naresh, J. Dubey, and J. Sharma: "Two-phase neural network based modelling framework of constrained economic load dispatch", IEE Proc. Generation, Transmission \& Distribution, Vol.151, No.3, pp.373-378 (2004)

( 7 ) Z. Guo-Li, L. Hai-Yan, and L. Geng-Yin: "Dynamic economic load dispatch using hybrid genetic algorithm and the method of fuzzy number ranking", Proc. of 2005 International Conference on Machine Learning and Cybernetics, Vol.4, pp.2472-2477 (2005)

(8) Z.Y. Miao, K. Yasuda, and R. Yokoyama: "Fuzzy dynamic load dispatching", 1991 International Conference on Advances in Power System Control, Operation and Management, pp.311-315 (1991)

(9) N. Yorino, Y. Fukuyama, and Y. Tamura: "A Time-suboptimal Method for Online ELD with Generation Rate Constraints", T. IEE Japan, Vol.108-B, No.4, pp.141-148 (1988-4) (in Japanese)

餘利野直人・福山良和・田村康男 :「変化率制約を考慮した ELD 問 題のオンライン時間準最適化法の提案」, 電学論 B, 108, 4, pp.141-148 (1988-4)

(10) K. Asano and T. Kumano: "Dynamic Economic Load Dispatch by Calculus of Variation Considering Ramp Rate", Proc. of the 8th International Power Engineering Conference-IPEC2007, Session TuP-2, Singapore (2007)

(11) Y. Fukuyama, N. Yorino, and Y. Tamura: "On-line ELD Scheme of 2-Level Structure for Coal Fired Units with Operating Constraints and Man-Machine Interface Taken Into Account", T. IEE Japan, Vol.107-B, No.4, pp.173-180 (1987-4) (in Japanese)

福山良和・餘利野直人・田村康男：「火力ユニットの諸制約とマン・ マシン・インタフェースを考慮した階層型オンライン ELD $」$, 電学論 B, 107, 4, pp.131-138 (1987-4)

（12）林 毅·村外志夫：変分法, コロナ社 (1983)

（13）寺沢寛一：自然科学者のための数学概論, 岩波書店 (1954)

（14）川崎英文：極值問題, 横浜図書 (2004)

\section{付 録}

\section{1. 変分 法}

本論文では動的経済負荷配分を条件付き変分問題として定 式化し, 本文 (11) 式に示す Eulerの微分方程式を解くことに よって関数最適化を行っている。付録 1 では参考文献(12) の記述を参考に Euler の微分方程式を解くことによって条 件付き変分問題が解ける理由を説明し，提案法の理論的基 盤を与える。

（1）付带条件付き変分問題と最適解の条件 本論文 で提案した手法はここで述べる付带条件付き変分問題の一 例である。付帯条件付き変分問題には種々の形のものがあ るが，提案法を含む一般的な形で，よく知られている定式
化について述べる。

関数 $y(x), z(x)$ に対して境界条件

$$
y\left(x_{o}\right)=y_{o}, y\left(x_{1}\right)=y_{1}, z\left(x_{o}\right)=z_{o}, z\left(x_{1}\right)=z_{1}
$$

が成り立ち, かつ $y$ と $z$ の間に束縛条件

$$
G\left(x, y, z, y^{\prime}, z^{\prime}\right)=0
$$

が成立すると仮定する。この場合に汎関数

$$
I[y, z]=\int_{x_{o}}^{x_{1}} F\left[x, y, z, y^{\prime}, z^{\prime}\right] d x
$$

を極值とするために（停留関数であるために）必要かつ十 分な条件は, 同じ境界条件の元で

$$
\hat{I}[y, z]=\int_{x_{o}}^{x_{1}}[F+\lambda(x) G] d x .
$$

を極值とすることである( の関数である)。これは

$$
\hat{F}=F+\lambda G
$$

に対して次の Eulerの微分方程式が成立することである。

$$
\frac{\partial \hat{F}}{\partial y}-\frac{d}{d x}\left(\frac{\partial \hat{F}}{\partial \dot{y}}\right)=0, \quad \frac{\partial \hat{F}}{\partial z}-\frac{d}{d x}\left(\frac{\partial \hat{F}}{\partial \dot{z}}\right)=0, \quad \frac{\partial \hat{F}}{\partial \lambda}=0
$$

（2）最適解条件の導出上で述べた (付 6) 式の条件 を導出する。ここで考えているのは関数 $y(x)$ と $z(x)$ の最適 化であるから，いかなる関数 $\eta(x)$ 㧍よび $\zeta(x)$ を用いて $y(x)$ と $z(x)$ を

$$
y^{\prime}(x)=y(x)+\alpha \eta(x), z^{\prime}(x)=z(x)+\alpha \zeta(x) \cdots
$$

と変更しても $\alpha$ にかかわらず (付 4) 式の積分が変化しない という条件である。ただし，ここで考えている条件では(付 1) 式に示したように $y(x)$ と $z(x)$ は考察区間の両端で固定 值をとる必要があるので

$$
\eta\left(x_{0}\right)=\eta\left(x_{1}\right)=0, \zeta\left(x_{0}\right)=\zeta\left(x_{1}\right)=0 \cdots \cdots \cdots
$$

なる条件が成り立つべきである。

さて，(付 4) 式の積分を実際に計算してみると $y$ と $z$ が 変化することによる I の変化 $\delta I$ は

$$
\begin{aligned}
\delta I= & \alpha \int_{x_{o}}^{x_{1}}\left[\frac{\partial F}{\partial y} \eta+\frac{\partial F}{\partial \dot{y}} \dot{\eta}+\frac{\partial F}{\partial z} \zeta+\frac{\partial F}{\partial \dot{z}} \dot{\zeta}\right] d x \\
& +\alpha \int_{x_{o}}^{x_{1}}\left[\frac{\partial(\lambda G)}{\partial y} \eta+\frac{\partial(\lambda G)}{\partial \dot{y}} \dot{\eta}+\frac{\partial(\lambda G)}{\partial z} \zeta+\frac{\partial(\lambda G)}{\partial \dot{z}} \dot{\zeta}\right] d x
\end{aligned}
$$

となる。右辺第一項の積分 ( $F$ に関する積分) で被積分関 数第 2 項および第 4 項と右辺第二項の積分 $(\lambda G$ に関する 積分）で被積分関数第 2 項および第 4 項にそれぞれ部分積 分を適用すると 


$$
\begin{aligned}
\delta I= & \left.\alpha \frac{\partial F}{\partial \dot{y}} \eta\right|_{x_{o}} ^{x_{1}}-\alpha \int_{x_{o}}^{x_{1}} \frac{d}{d x}\left(\frac{\partial F}{\partial \dot{y}}\right) \eta d x \\
& +\left.\alpha \frac{\partial F}{\partial \dot{z}} \zeta\right|_{x_{o}} ^{x_{1}}-\alpha \int_{x_{o}}^{x_{1}} \frac{d}{d x}\left(\frac{\partial F}{\partial \dot{z}}\right) \zeta d x \\
& +\left.\alpha \frac{\partial(\lambda G)}{\partial \dot{y}} \eta\right|_{x_{o}} ^{x_{1}}-\alpha \int_{x_{o}}^{x_{1}} \frac{d}{d x}\left(\frac{\partial(\lambda G)}{\partial \dot{y}}\right) \eta d x \\
& +\left.\alpha \frac{\partial(\lambda G)}{\partial \dot{z}} \zeta\right|_{x_{o}} ^{x_{1}}-\alpha \int_{x_{o}}^{x_{1}} \frac{d}{d x}\left(\frac{\partial(\lambda G)}{\partial \dot{z}}\right) \zeta d x \\
& +\alpha \int_{x_{o}}^{x_{1}}\left[\frac{\partial F}{\partial y} \eta+\frac{\partial F}{\partial z} \zeta+\frac{\partial(\lambda G)}{\partial y} \eta+\frac{\partial(\lambda G)}{\partial z} \zeta\right] d x
\end{aligned}
$$

ここで(付 8) 式の条件を考慮すると上式は次のように書き 直せる。

$$
\begin{aligned}
\delta I= & -\alpha \int_{x_{o}}^{x_{1}} \frac{d}{d x}\left(\frac{\partial F}{\partial \dot{y}}\right) \eta d x-\alpha \int_{x_{o}}^{x_{1}} \frac{d}{d x}\left(\frac{\partial F}{\partial \dot{z}}\right) \zeta d x \\
& -\alpha \int_{x_{o}}^{x_{1}} \frac{d}{d x}\left(\frac{\partial(\lambda G)}{\partial \dot{y}}\right) \eta d x-\alpha \int_{x_{o}}^{x_{1}} \frac{d}{d x}\left(\frac{\partial(\lambda G)}{\partial \dot{z}}\right) \zeta d x \\
& +\alpha \int_{x_{o}}^{x_{1}}\left[\frac{\partial F}{\partial y} \eta+\frac{\partial F}{\partial z} \zeta+\frac{\partial(\lambda G)}{\partial y} \eta+\frac{\partial(\lambda G)}{\partial z} \zeta\right] d x
\end{aligned}
$$

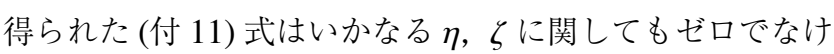
ればならないので

$$
\left.\begin{array}{l}
\frac{\partial F}{\partial y}-\frac{d}{d x}\left(\frac{\partial F}{\partial \dot{y}}\right)+\frac{\partial(\lambda G)}{\partial y}-\frac{d}{d x}\left(\frac{\partial(\lambda G)}{\partial \dot{y}}\right)=0 \\
\frac{\partial F}{\partial z}-\frac{d}{d x}\left(\frac{\partial F}{\partial \dot{z}}\right)+\frac{\partial(\lambda G)}{\partial z}-\frac{d}{d x}\left(\frac{\partial(\lambda G)}{\partial \dot{z}}\right)=0
\end{array}\right\}
$$

でなければならない。これらと付带条件 (付 2) を合わせて 書いたものが既出 (付 6) 式である。

（3）自然境界条件の場合 上で述べたのは境界点(端 点） $x_{o}, x_{1}$ に打いてともに(付 1$)$ 式の固定境界条件が成り 立つ場合である。しかし本文で述べたケースでは考察領域 の始点と終点では個々の発電機出力について明確に固定值 とすべき理由はない。このような場合には自然境界条件

$$
\frac{\partial \hat{F}}{\partial \dot{y}}=0, \quad \frac{\partial \hat{F}}{\partial \dot{z}}=0
$$

が成り立つことが要求される。これは (2) 項の導出におい て (付 10) 式を(付 11) 式のように書き直すところで

$$
\left.\alpha \frac{\partial F}{\partial \dot{y}} \eta\right|_{x_{o}} ^{x_{1}}
$$

等の項をゼロとするために必要である。Euler の微分方程 式は前項と同じ形となる。

（4）まとめ上で述べたことょり，(付 3) 式に示す 積分を (付 2) 式の付帯条件の元で最小化する関数最適化を 行うには，境界の性質に応じて固定境界条件 (付 1) あるい は自然境界条件 (付 13) の元で (付 6) 式の Euler の微分方程 式を解けばよいことが分かる。ここで述べた理論の詳細に ついては文献(12)〜(14) 等を参照されたい。

\section{2. 提案法で取り扱う微分方程式}

提案法で解いている Euler の微分方程式 (本文 (11) 式) の具体的な形を以下に記す。発電機 $i$ に対して

$$
\begin{aligned}
b_{i} & +2 c_{i} P_{i}+w_{i 3}^{\prime}\left(P_{i}\right)+w_{i 4}^{\prime}\left(P_{i}\right)+2 A\left(P_{i}-P_{i m}\right) \\
& \left.-2 c_{i} \ddot{P}_{i}-d w_{i 1}\left(\dot{P}_{i}\right)-d w_{i 2}\left(\dot{P}_{i}\right)+\lambda=0 \cdots \text { (付 } 14\right)
\end{aligned}
$$

であり, $i=1, \ldots, \mathrm{NG}$ に関して同様の式が成り立つ。二重 傍点は時間变数による二階微分を意味し, ペナルティ関数 項 $w_{i 3}^{\prime}, w_{14}^{\prime}, d w_{i 1}, d w_{i 2}$ の具体的な内容は以下のと拈りで ある。

$$
\begin{aligned}
& d w_{i 1}\left(\dot{P}_{i}\right)= \begin{cases}0 \quad\left(\dot{P}_{i} \leq \dot{P}_{i 1 o}\right) \\
\frac{\ddot{P}_{i}}{\left(\dot{P}_{i}-\dot{P}_{i \max }\right)^{2}} \quad\left(\dot{P}_{i}>\dot{P}_{i 1 o}\right)\end{cases} \\
& d w_{i 2}\left(\dot{P}_{i}\right)= \begin{cases}0 & \left(\dot{P}_{i} \geq \dot{P}_{i 2 o}\right) \\
\frac{\ddot{P}_{i}}{\left(\dot{P}_{i}-\dot{P}_{i \min }\right)^{2}} & \left(\dot{P}_{i}<\dot{P}_{i 2 o}\right)\end{cases} \\
& w_{i 3}^{\prime}\left(P_{i}\right)=\left\{\begin{array}{l}
0 \quad\left(P_{i} \leq P_{1 o}\right) \\
-\frac{1}{P_{i}-P_{i \max }}-\frac{1}{P_{i \max }-P_{i 1 o}} \quad\left(P_{i}>P_{i 1 o}\right)
\end{array}\right. \\
& w_{i 4}^{\prime}\left(P_{i}\right)=\left\{\begin{array}{l}
0 \quad\left(P_{i} \geq P_{2 o}\right) \\
-\frac{1}{P_{i}-P_{i \min }}-\frac{1}{P_{i \min }-P_{i 2 o}} \quad\left(P_{i}<P_{i 2 o}\right)
\end{array}\right)
\end{aligned}
$$

関数 $w_{13}^{\prime}\left(P_{i}\right)$ 等における「'」(ダッシュ記号) は発電機出力 $P_{i}$ による微分を意味し, 関数 $d w_{i 1}$ 等に打ける $d$ は時間変 数による微分の意味で用いている。この方程式を時間 $t$ で 積分すれば任意時点での各発電機の出力值を得る。

この微分方程式は二階の非線形方程式であり，未知数の 数を $n$ とすれば, $n$ 個の状態変数に関する值を二点で与え るか, あるいはこれらの変数值と微分係数の両者を一点で 与えることで解くことができる。

変分法によれば，この問題は本来二点での関数值あるいは 状態変数の微分係数に関する偏微分值を与えることによっ て解く必要があるが，これは数值的に解くのが難しいため, 本論文ではこれを一点に㧤いて変数值と微分倸数の両者を 与えることで解く。

\section{Newton 法による求解の具体的内容}

提案法で行う Newton 法による求解の際に解いている方 程式の具体的な形を以下に記す。まず, 解く方程式は, 発 電機 $i=1,2, \ldots, \mathrm{NG}$ に関して (付 14), (付 15) 式と本文 (14) 式が成り立つので次のようになる。解析対象時間範 囲中の任意の時刻 $t$ に関して $P_{1}(t-\Delta t), \ldots, P_{N G}(t-\Delta t)$ および $Q_{1}(t-\Delta t), \ldots, Q_{N G}(t-\Delta t)$ は既知であり, 総需要 $P_{L}(t)$ も与えられているとしているので, これらを用いて $P_{1}(t), P_{2}(t), \ldots, P_{N G}(t)$ と $Q_{1}(t), Q_{2}(t), \ldots, Q_{N G}(t)$ ならびに $\lambda(t)$ の值を求めることを考える。 


$$
\begin{aligned}
& b_{1}+2 c_{1} P_{1}+w_{13}^{\prime}\left(P_{1}\right)+w_{14}^{\prime}\left(P_{1}\right)+2 A\left(P_{1}-P_{1 m}\right) \\
& \quad-2 c_{1} \dot{Q}_{1}-d w_{11}\left(Q_{1}\right)-d w_{12}\left(Q_{1}\right)+\lambda=0 \\
& \dot{P}_{1}-Q_{1}=0 \\
& \cdots \\
& \quad \ldots \\
& \quad+2 A\left(P_{N G}-P_{N G m}\right)-2 c_{N G} \dot{Q}_{N G}-d w_{N G 1}\left(Q_{N G}\right) \\
& \quad-d w_{N G 2}\left(Q_{N G}\right)+\lambda=0 \\
& \dot{P}_{N G}-Q_{N G}=0 \\
& P_{1}+P_{2}+\cdots+P_{N G}=P_{L}(t)
\end{aligned}
$$

つまり

$$
\begin{aligned}
& b_{1}+2 c_{1} P_{1}(t)+w_{13}^{\prime}\left(P_{1}(t)\right)+w_{14}^{\prime}\left(P_{1}(t)\right) \\
& +2 A\left(P_{1}(t)-P_{1 m}\right)-2 c_{1} \frac{Q_{1}(t)-Q_{1}(t-\Delta t)}{\Delta t} \\
& -d w_{11}\left(Q_{1}(t)\right)-d w_{12}\left(Q_{1}(t)\right)+\lambda(t)=g_{1}=0 \\
& \frac{P_{1}(t)-P_{1}(t-\Delta t)}{\Delta t}-Q_{1}(t)=g_{2}=0 \\
& \text {... } \\
& \left.\begin{array}{l}
b_{N G}+2 c_{N G} P_{N G}(t)+w_{N G 3}^{\prime}\left(P_{N G}(t)\right)+w_{N G 4}^{\prime}\left(P_{N G}(t)\right) \\
\quad+2 A\left(P_{N G}(t)-P_{N G m}\right) \\
\quad-2 c_{N G} \frac{Q_{N G}(t)-Q_{N G}(t-\Delta t)}{\Delta t}-d w_{N G 1}\left(Q_{N G}(t)\right) \\
\quad-d w_{N G 2}\left(Q_{N G}(t)\right)+\lambda(t)=g_{N G-2}=0 \\
\frac{P_{N G}(t)-P_{N G}(t-\Delta t)}{\Delta t}-Q_{N G}(t)=g_{N G-1}=0 \\
P_{1}(t)+P_{2}(t)+\cdots+P_{N G}(t)-P_{L}(t)=g_{N G}=0
\end{array}\right\}
\end{aligned}
$$

未知数の数と方程式の数は共に $2 \mathrm{NG}+1$ 本であるので, 原 理的にはこれは解けると期待される。実際に解こうとする 場合問題になるのは $w_{i 3}^{\prime}, w_{14}^{\prime}, d w_{i 1}, d w_{i 2}$ が非線形である 点であるが，Newton 法を用いて次に示す修正量に関する 方程式を用いて反復収束計算を行えばよい。

$$
\begin{gathered}
{\left[\begin{array}{ccccc}
J_{1,1} & J_{1,2} & \cdots & J_{1,2 N G} & J_{1,2 N G+1} \\
J_{2,1} & J_{2,2} & \cdots & J_{2,2 N G} & J_{2,2 N G+1} \\
\vdots & \vdots & \ddots & & \vdots \\
J_{2 N G, 1} & J_{2 N G, 2} & & J_{2 N G, 2 N G} & J_{2 N G, 2 N G+1} \\
J_{2 N G+1,1} & J_{2 N G+1,2} & \cdots & J_{2 N G+1,2 N G} & J_{2 N G+1,2 N G+1}
\end{array}\right]\left[\begin{array}{c}
\Delta P_{1}(t) \\
\Delta Q_{1}(t) \\
\vdots \\
\Delta Q_{N G}(t) \\
\Delta \lambda(t)
\end{array}\right]} \\
=\left[\begin{array}{lllll}
\Delta g_{1} & \Delta g_{2} & \cdots & \Delta g_{N G-1} & \Delta g_{N G}
\end{array}\right]^{T}
\end{gathered}
$$

ただしヤコビ行列の要素は次に示すとおりである。

$$
\left.\begin{array}{l}
J_{1,1}=2 c_{1}+\frac{d}{d P_{1}} w_{13}^{\prime}+\frac{d}{d P_{1}} w_{14}^{\prime}+2 A \\
J_{1,2}=-\frac{2 c_{1}}{\Delta t}-\frac{d}{d Q_{1}} d w_{11}-\frac{d}{d Q_{1}} d w_{12} \\
J_{1,3}=0 \\
\vdots \\
J_{1,2 N G}=0 \\
J_{1,2 N G+1}=1.0 \\
J_{2,1}=\frac{1}{\Delta t} \\
J_{2,2}=-1.0 \\
J_{2,3}=0 \\
\vdots \\
J_{2,2 N G+1}=0 \\
\vdots \\
J_{N G, 1}=J_{N G, 3}=\cdots=J_{N G, 2 N G-1}=1 \\
J_{N G, 2}=J_{N G, 4}=\cdots=J_{N G, 2 N G}=J_{N G, 2 N G+1}=0
\end{array}\right\}
$$

熊 野 照 久（上級会員） 1963 年 2 月 4 日生。 1990 年 3 月東

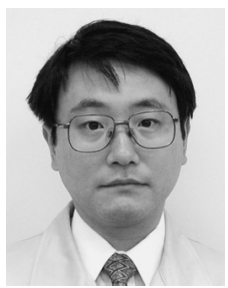
京大学大学院博士課程修了。工学博士。同年 4 月 (財) 電力中央研究所入所。2004 年 11 月明治大学 助教授。2003 年電気学術振興賞 (論文賞) 受賞。 電力系統と電力用大型回転機の解析 $\cdot$ 運用・制御 の研究に従事。電子情報通信学会, IEEE, ISAL 会員。 